\title{
DESIGN OF THE SENSORY SYSTEM IN THE INTELLIGENT ASSEMBLY CELL
}

\author{
RUZAROVSKY, R[oman]; SEBENOVA, S[ilvia] \& VELISEK, K[arol]
}

\begin{abstract}
Intelligent assembly cell conception includes new solution kind of how to create structures of automated and flexible assembly system. Intelligent behavior of the system as the control system will repose on monitoring of important parameters of the system in the real time. The designed automation sensory equipment provides for automatic monitoring of all automated equipment motions in the first case and in the second important level is important to obtain the information about the status, presence and character of the assembled objects or assembly process. The application of the sensory equipment in the intelligent assembly process is designed on the ground of the sensory object properties of the pneumatic actuator model. In the paper is described the sensor equipment application for the assembly part sorting situated before the input of the object into the assembly process and for the check function of assembly product is designed the combination of sensory equipment.
\end{abstract}

Key words: assembly process, assembly cell, intelligent assembly, sensory, design

\section{INTRODUCTION}

Intelligent assembly cell is characterized as the assembly system cell conception with automates assembly device, inputs and outputs of the assembly objects. "Intelligent" behavior of assembly system is defined and controlled by help of sensory equipment and this information from sensory system processes the "brain" of the intelligent assembly cell - control system. Control system with sensory equipment monitors the important parameters of system operation and its interaction between system and the environment on the ground of the obtained data in the flexible system reaction in the real time (Hrušková \& Matúšová, 2010). Implementation and utilization of this conception of the intelligent assembly cell brings the flexible adaptation and system reaction to changes in the production requirements and also changes in the system environment (Hrušková et al, 2010).

\section{INTELLIGENT ASSEMBLY CELL DESIGN}

Intelligent assembly cell conception, created for part production, or small series production, is an assembly system with some intelligent degree, which manipulate with semiproducts and parts, which are assembled in the system to the final product (Velíšek et al., 2005). For manipulation and assembly is not used external industrial robot, that is the point in which is this system other than traditional assembly systems. Second important device provides for manipulation and storage by shelf storage with manipulator. On the Fig. 1 is showed developed intelligent assembly cell at Institute of manufacturing systems and applied mechanics.

Basic structure of the intelligent assembly cell is divided to subsystems and its automated devices: assembly device, manipulating device, storage system, rotary input and output device and control system (Danišová \& Majerník, 2010). All these parts are controlled independently to other devices. The control system provides the regulation, operation and coordination between all systems. Intelligent assembly cell have to integrate four main phases. Products proceed through all of them.

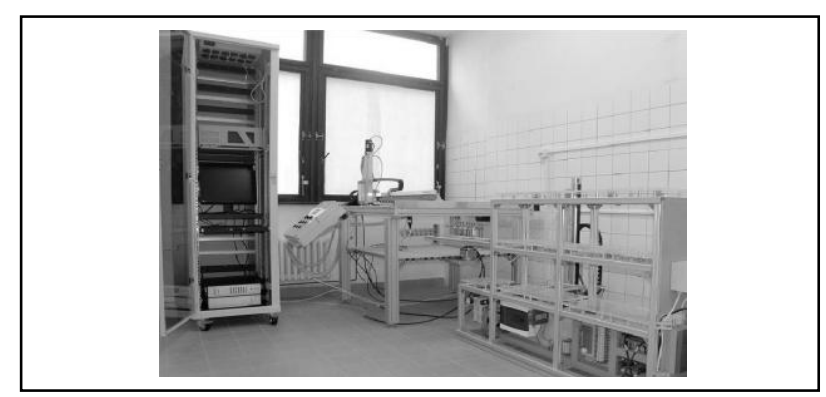

Fig. 1. Main units of the intelligent assembly cell

Material flow of final product is included into main phases: semi-product storage and transport to the assembly device, particular elements manipulation and orienting, assembly to one entity as final assembly product, final product manipulation and storage to next expedition. Basic layout is showed on the Fig. 2.

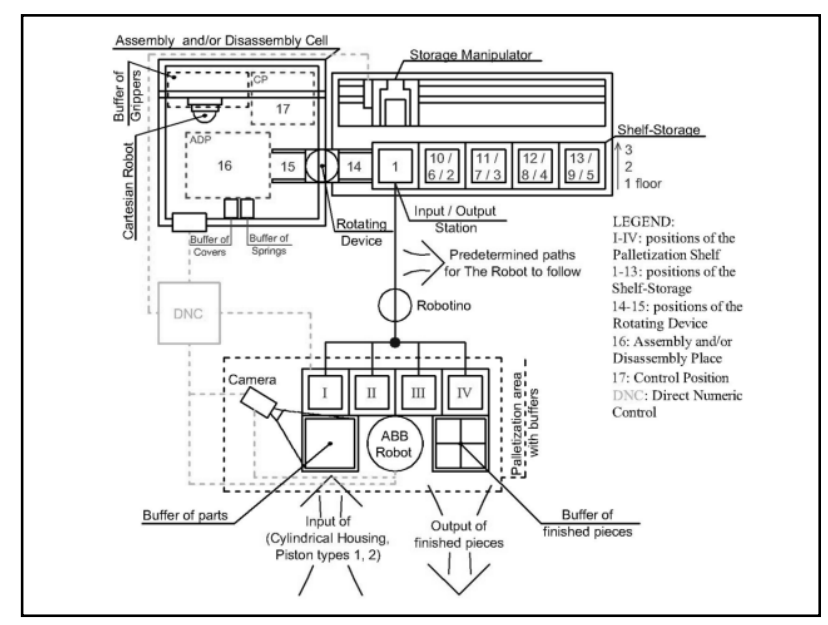

Fig. 2. Basic layout of the intelligent assembly cell

\section{EXPECTED TASK OF SENSORY SYSTEM}

The degree of manufacturing cell intelligent will be realized by sensors equipment of cell control system. The aim is to create flexible reactions of assembly cell to the manufacturing requests, which will be imported as incoming data to the system. Sensors are one of the necessary components in the development of intelligent assembly systems. Basic sensing components, like robot vision, tactile sensors and force torque components, are indispensable in these systems (Danišová \& Majerník 2010). The sensory system has to sense the system state and adjust the assembly system by help of the control 
system. For the examination of the system and the environment will be used vision systems with CCD camera. Vision system will be sense the status in the shelf storage, assembly robot and also the orienting and positioning of the parts.

The sensor is an input device which is used to measuring the actual value some physical quantity. Detection of the system state and measurement is implemented by using of various types of sensors. It is not able to exact defined and design the right sensor for concrete application by design of the intelligent assembly cell. Generally is possible to design the sensory equipment in the three basic applications grounded on the requsted operations in the assembly process (Fig. 3).

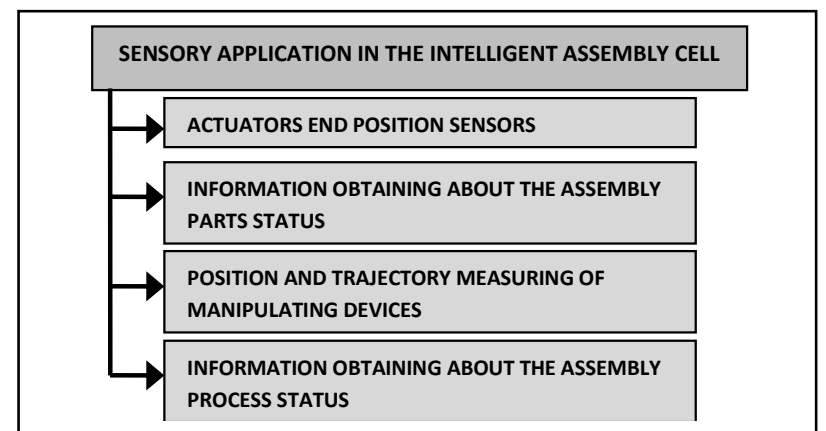

Fig. 3. Sensor equipment application possibilities in the intelligent assembly cell

The application of the sensory equipment in the intelligent assembly process is very important and the design of it is realized on the ground of the sensory object properties. In the first case are used standard sensors for obtaining of the end positions of the actuators and information about position of the pallets or number of pallet in the shelf storage system. For the design of the intelligent assembly cell is important to deal with the second and last group of the sensor equipment. In the second level is important to obtain the information about the status, presence and character of the assembled objects or assembly process.

\section{SENSORY SYSTEM APPLICATION IN THE INTELLIGENT ASSEMBLY CELL}

Main application of the sensors is the sensing of the assembly object state, presence and character. On the grounf of the assembly product analyse is realized the design of sensory equipment. The assembly group analyse is divided to main operations: size, weight, shape, parts quantity, material, assembly base and assembly joints analyses. On the ground of these analyses are designed main sensors for the pneumatic actuator object assembly sorting (Fig. 4). The sensors are situated before the input of the object into the assembly process. For the sorting are designed inductive and optical digital sensors (Javorová et al, 2011).

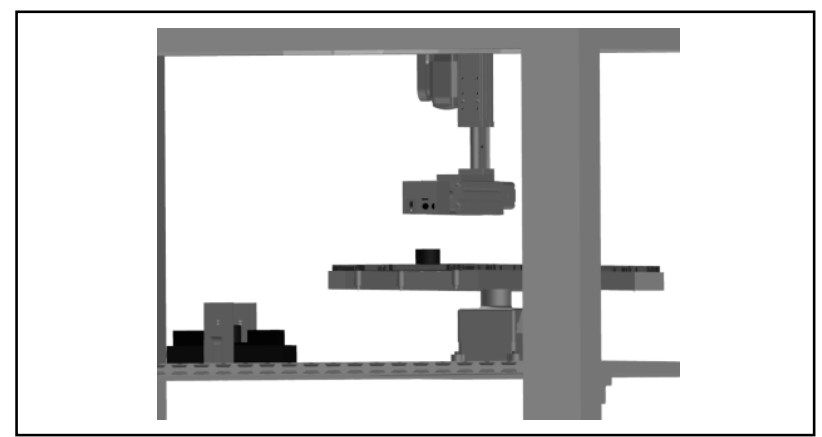

Fig. 4. Design of the sensory equipment for the object sorting
Also are designed the optical and pressure sensors that monitored the assembly process in the intelligent assembly cell defined as assembly operation control (Fig. 5). The assembly operation is realized by help of the Cartesian industrial robot and automatic fixture clamping system. For the check function of assembly product is designed the combination of sensory equipment.

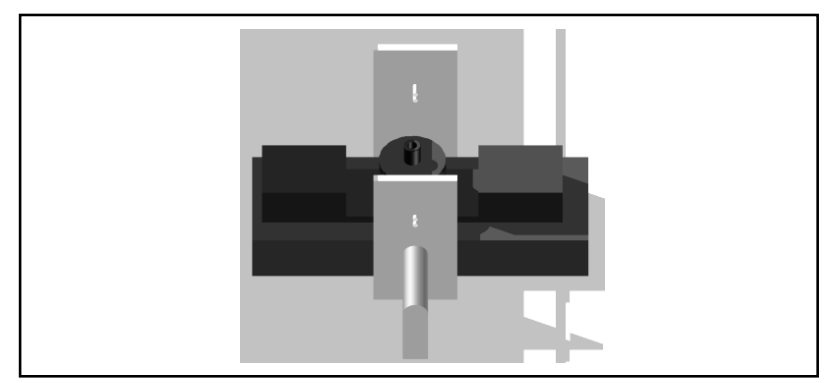

Fig. 5. Design of the sensory system in the assembly operation

\section{CONCLUSION}

Intelligent assembly cell is developed on the ground of designed hardware of the flexible assembly cell that provides the performance of the assembly process. On the ground of the theoretical and practical analyze is needed to design the algorithm of the intelligent assembly cell "intelligent" behaviour. By synthesis of reached knowledge will be created and intelligent model of such intelligent assembly system. The behavior of such intelligent system will reside in monitoring process of important working parameters of the system. Detail prepared algoritm define the important nodes in the assembly process that will be monitored by the designed sensory system.

\section{ACKNOWLEDGEMENTS}

This paper was created thanks to the national grant: VEGA 1/0206/09 - Intelligent assembly cell.

\section{REFERENCES}

Danišová, N. \& Majerník, J. (2010). Sensors design in the shelf storage system, Annals of Faculty of Engineering Hunedoara - Journal of Engineering, Tom VIII, Fasc 3, p. 367-370 ISSN 1584-2673

Danišová, N. \& Velíšek, K. (2009), Intelligent assembly system, Annals of MTeM for 2009 \& Proceedings of the 9th International Conference Modern Technologies in Manufacturing, 8th - 10th October 2009, Cluj-Napoca, Romania, Cluj-Napoca, ISBN 973-7937-07-04, p. 57-60, Technical University of Cluj-Napoca

Hrušková, E.; Holubek, R. \& Velíšek, K. (2010). The possibilities of increasing the flexibility of intelligent assembly cell. ASME 2010 10th Biennial Conference on Engineering Systems Design and Analysis (ESDA2010), Turkey, Istanbul, ISBN 978-0-7918-3877-8, p. 1-10, ASME

Hrušková, E. \& Matúšová, M. (2010) Flexibility approach to effectiveness increasing of assembly cell. Annals of DAAAM and Proceedings of DAAAM Symposium, Vol. 21, No 1. Annals of DAAAM for 2010 \& Proceedings of the 21 st International DAAAM Symposium "Intelligent Manufacturing \& Automation: Focus on Interdisciplinary Solutions" 20-23rd October 2010, Zadar, Croatia, ISSN 1726-9679, ISBN 978-3-901509-73-5, p. 0221-0222, DAAAM International Vienna

Javorová, A.; Hrušková, E. \&Matúšová, M. (2011). Automated design of assembly system with computer aided system help. Journal of Production Engineering, Vol. 14, Number 1, p. 31-34 ISSN 1821-4932

Velíšek, K. et al. (2005). Assembly machines and devices, STU, ISBN 80-227-2187-5, Bratislava 